\title{
THE WAYS OF IMPROVEMENT OF THE TAX CONTROL SYSTEM IN RUSSIA IN THE NEW GEOPOLITICAL CONDITIONS BASED ON HISTORICAL EXPERIENCE AND WORLD PRACTICE
}

\author{
Elena Mikhaseva \\ $P h D$ in Economics \\ Volgograd branch of the Russian Presidential Academy of National Economy \\ and Public Administration \\ 8 Gagarina str., Volgograd, Russian Federation, 400131 \\ zhen0505@mail.ru
}

\begin{abstract}
Creation of the financial stability is the main task of any state, in which connection the value of taxes and duties as the sources of profitable part of the state budget explains priority of the tax control as the direction of tax authorities' activity. Economic and social development of any modern state much depends on effectiveness of tax control system that is why the problems of tax control organization, elaboration of the ways of tax control improvement are topical. In the modern world the international relations and connections gain the great value, at the state interaction they can appeal to the experience of each other on the questions of legislation, levy of the taxes and duties in the state budget. In each state the tax control systems are different and have both positive and negative aspects. At analysis of the foreign legislation the detailed analysis of the results of the use of certain measures of regulation and control is needed and it is also necessary to prognosticate an experience that will be gained by our state in the case of introduction of analogous measures. It is also must be noted that for creation of the effective tax control system it is necessary to use the large number of mechanisms of tax administration.

Keywords: tax control, tax audits, tax authorities, foreign experience, retrospective analysis.
\end{abstract}

\section{Introduction}

Russian Federation as the democratic federative legal and social state acting in the interests of whole society for observance and protection of human rights and freedoms, realizes the social, economic, law-enforcement and other functions that are provided by the tax proceeds. For uninterrupted financing of these arrangements especially in the modern geopolitical conditions the replenishment of budget of all levels is needed and this, in its turn, is attained mainly at the expense of taxes, duties and other compulsory payments made by the juridical and natural persons. But for many reasons taxpayers pay tax payments not always timely and in full that is why the special organizational-regulatory mechanism is needed for guaranteeing the money proceeds in the state budget system. It is well-known that economic and social development of any modern country depends on the development of tax control mechanism. At this stage creation of financial stability is the main task of the state, and the value of taxes and duties as the sources of the profitable part of state budget explains the priority of tax control as the direction of tax authorities' activity. That is why the problems of the tax control organization and elaboration of the ways of the tax control improvement are topical for today. In this research are considered the historical aspects of tax control, given the assessment and carried out the comparative analysis of the foreign practice of tax control realization what, in its turn, allowed separate the directions of improvement of the existing tax control system. The adaptation of foreign experience is offered with taking into account the national features of Russia and mentality of Russian citizens and also with reference to the historical experience of Russian state.

\section{Analysis of the literature data and statement of the problem}

In the research were used the works of other scientists. For studying the foreign practice were considered the works on the following questions: tax audits in United States of America [1]. The aim of the study of this source was the search for information about USA according to the set 
criteria. The appeal to this source allowed collect information on all set criteria of assessment of the tax control system of USA. At the study of the tax systems of the foreign countries [2] we were also aimed at the search for information on the set criteria for comparative analysis. In the whole the needed information was obtained on the all set criteria. Studying the material on the tax control practice in the foreign countries [3] we selected the information on the set criteria. This source allowed collect the information on the set criteria in full. The aim of studying the features of tax system and tax control in France [4] was the search for information about France on the set criteria of assessment used in the research. The appeal to this source allowed select information on the all set criteria of assessment of the tax control system in France. I selected the main criteria of assessment of the tax control systems of selected countries and carried out the comparative analysis of the studied material. The selection of countries was not occasional; it was also based on the defined principles.

The study of such scientific works: on the problems of determination of economic base of tax according to the Russian legislation and in the practice of the Russian courts [5] allowed to prove the existence of this problem and the necessity to search for the ways of its solution. The problems at the investigation of the tax crimes [6] were studied for revelation of the features connected with the investigation of the tax crimes what, in its turn, proves the correctness of conclusions of the given research about the adoption of the positive foreign experience at introduction of the institution of the tax court and tax policy.

The materials of the chief of Federal tax service of Russia [7] about the rise of quality and effectiveness of the tax administration were studied for definition of the main directions of the tax control improvement at the modern stage.

For studying the historical experience was considered the following source: Organization of the direct taxation in the Moscow state [8], it allowed separate within the research the main stages of formation and development of the tax control system in Russia.

For the comparative analysis of the foreign practice, studying of the historical experience and existing tax control system in Russia was also used the information from the official site of the Federal tax service [9].

\section{Aims and tasks of research}

The aim of the work is the definition of the main directions of improvement of the tax control system in Russia.

For attainment of the set aim were set the following tasks:

1. To give the brief characteristic of the existing tax control system of Russia.

2. To carry out the retrospective analysis of the formation and development of the tax control system in RF.

3. To carry out the comparative analysis of the foreign experience in the tax control, to compare the principles and methods of the tax control realization.

4. To formulate and systematize the main directions of the tax control improvement on the base of the studied historical and foreign experience.

\section{Materials and methods of research}

Tax control is the important component of the tax system of any country that conditions the fullness and timeliness of the tax proceeds in budget, economic safety and prevention of the tax crimes. Tax control in Russia is the complex and purposeful system of economic and legal actions of authorized state power representatives that is based on the taxation legislation and is directed on the collection and analysis of information about the discharge by the tax payers of their duty on tax payment. The main aim of the tax control is the guaranteeing of the tax legislation compliance by the subjects of the tax legal relationship. Tax control is based on the principles of legality, objectiveness, regularity, generality, unity. Realizing the tax control the tax authorities use the methods of the preliminary observance, current control and subsequent control. The base (foundation) of the tax control is the accounting of the tax payers. In Russia the arrangements of tax control are the following: access of the officials on the territory or in accommodation for the tax audit, inspection, vindication 
of documents, seizure of documents and objects, expertise, involvement of specialist. In Russia the tax control arrangement can be divided into: the main, accessory and additional ones [10]. The special feature of the tax control in Russia is the process of selection of the tax payers for the field tax audit: it is the absolutely open process, that is tax payers and tax authorities use the unified criteria of selection, so each subject of economy can assess his probability of the field audit, the tax authorities, in its turn, follow just these "open" criteria of assessment of the tax risks. The tax code of Russia contains two types of the audit: the field and cameral ones. The main and the most effective form of control is the field audit. Just within the field audit can be revealed the most important and essential tax offences and crimes. Summing up the aforesaid we can make a conclusion that the tax system of Russia is rather modern, corresponds to the common world standards and has the serious regulatory legislative base. The effective tax control system is such that allow reach the balance at the full and timely replenishment of state budget without the increase of the tax load on the conscientious tax payers.

So the age-old Russian system of taxation elaborated the different forms and methods of control on the tax collection and tax legislation compliance. The development and change of these forms were conditioned by the development of economic and legal institutions. Carrying out the retrospective analysis of the formation and development of the system of tax administration in Russia we can separate the following main stages (Table 1).

The history of Russian tax authorities mainly corresponds to the tendencies observed in the world history.

The special feature of the tax authorities' development in Russia is its gradual isolation as the specialized authorities which function is the control on the taxes and duties collection. At the beginning such control and strictly speaking tax collection was realized by the authorities responsible for the others tasks not connected with the tax relations. Then the tax authorities existed in the system of financial institutions responsible for both incomes and outcomes of the budget. Finally nowadays took place the separation of the tax and financial institutions that exist for today as the separate authorities of executive power. At the modern stage the tax control system is also in the dynamic development. Among the modern methods of the tax control improvement in Russia can be separated the following ones:

- rise of availability level of the state services;

- rise of the balance level of the control-supervisory arrangements in the activity of business subjects;

- rise of effectiveness of interaction between the tax authorities and tax payers;

- modernization of the system of information exchange at the interdepartmental level;

- creation of the favorable tax conditions for investment activity realization on the separate territories;

- the special preferential tax regime for investment activity and in first turn for investments in high technological and knowledge-based branches, in creation of the additional conditions for intensification of innovative activity, in maximally preferential taxation of the productive sector and low-paid wage labor;

- improvement of the system of tax payers selection for the control audits that gives a possibility to select the most optimal direction of the maximal effectiveness of tax audits at the minimal costs and forces, at the expense of selecting for audits such tax payers which probability of revelation of the tax offence seems to be the highest one.

For the full and timely informing of the population on the taxation questions, giving the consulting help for the tax payers are necessary:

- to strengthen the system of information-explanative work for the tax payers;

- to guarantee the permanent participation of the workers of the law-enforcement authorities and control authorities in seminars of the different educational centers for explanation of the state policy and currency legislation;

- to hold the consulting conferences, meetings with representatives of the producers unions, entrepreneurs associations on the taxation problems. 
Table 1

The main stages of formation and development of the tax administration system in Russia

\begin{tabular}{cl}
\hline Dates & \multicolumn{1}{c}{ Stage description (Stage specificity) } \\
\hline X century & In the Old Russian principalities the replenishment of coffers was realized with the help of tribute levy. The tribute \\
wasually levied by the "polyude" at the visitation of the subordinated territories by the prince or prince squad. \\
(Tribute was the prototype of the direct taxes) \\
In the times of Tatar-Mongol Yoke the Golden Hordes collected tribute from the dependent territories at the beginning \\
With the help of representatives of khan - baskaks then this mission was entrusted to the local authorities: so the Russian \\
century \\
appanage princes collected tributes on their territory and then gave it to the grand prince for sending to the Hordes. \\
(Baskaks and appanage princes were the prototypes of the tax authorities)
\end{tabular}

The post of strangle inspector appears. The functions of the strangle inspectors were the control on the correct tax collec-

1885 year tion in their districts and administration of the uyezd strangle institutions activity.

(Appearance of the structural units in the tax authorities that are responsible for the control on the correctness of accounting and collection of the tax payments)

1918 year By the decree of the CNC the tax collection was entrusted to the management of the created financial departments of the region and uyezd executive committees (Transfer of the fiscal function to the new state authority)

In the National finance committee was formed the management of taxes and state incomes and the control on the tax

1921 year collection is entrusted to the financial inspectors subordinated to the region financial departments.

(Formation of the new authority responsible for the collection and control of the tax payments)

1930 year Creation of the tax inspections in the system of district and city financial departments. (Appearance of the new structural unit in the system of tax administration)

1946 year National financial committee of USSR was transformed into the Finance Ministry of USSR. (Transformation of the authority responsible for the finances of USSR)

Creation of the Major state tax inspection of the Finance Ministry of USSR. The State tax service - the separate authority

1990-1991 of executive power of the federal level independent from the Finance ministry of Russia was created (Russia transition to

years the market economy caused the necessity of reorganization of the authorities that realize tax collection. The state tax service becomes the separate authority of executive power of the federal level, independent from the Finance Ministry of Russia)

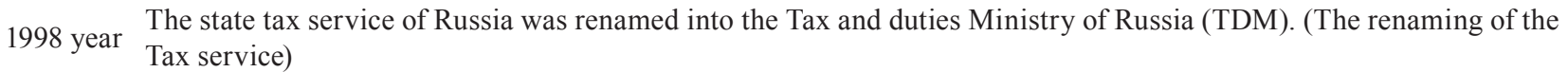

1999 year The 1 part of the Tax code of Russian Federation that establishes the main principles of taxation was introduced into practice. (Introduction of the basic regulatory act for the tax system of RF)

For creation of the united information base on the control and monitoring of the tax payers' activity:

- from 15 January 2016 was created the "united system of administration of the tax and non-tax (equated to the tax ones) payments within the Finance Ministry system in such a way that the Federal tax service responsible for the general methodical management, administration and tax collection was preserved within this system". In particular, the system must include the Pension Fund (PFR), Social Insurance Fund (SIF) and the Obligatory Medical Insurance Fund (OMIF) and 
also the Russian Alcohol Regulation (RAR). So the main sources of income of the federal budget are concentrated in the Finance Ministry.

- integration of the services, information systems of the tax and customs services. Innovation allows raise the quality of payments administration and business transparency;

It must be noted that the unified fiscal institutions that combine tax and customs service exist also in the other countries, for example, in Great Britain and Germany. In Germany the customs service is also the department of the Finance Ministry.

But there are also the opposite examples. For example, in USA the customs authorities are coordinated by the separate institution that also protects borders (U. S. Customs and Border Protection). It is subordinated to the Ministry of the national security.

So for the choice of the optimal and effective model of the tax control system it is reasonable to appeal also to the foreign experience of the several countries: Germany, Japan, France, Italy, Canada, Sweden and USA. The choice of the countries is not occasional and is conditioned by the difference in geographic and continental position and mentality of the population of the aforesaid countries, for example, Germany is considered as the country with the one of the most conservative tax systems. The tax system of Japan is the one of the most effective in the world. The tax system of France is known for its specificity. The tax system of USA is familiar to the tax system of Russian Federation.

In the centuries-old practice of taxation were elaborated the different forms and methods of the control on the tax collection, tax legislation compliance. The development and change of these forms were conditioned by the development of economic and legal institutions. Let us carry out the comparative analysis of the tax control in Russia and the foreign countries according to the following criteria (Table 2).

\section{Table 2}

Comparative analysis of the realization of the tax control functions in the foreign countries and in Russian Federation

\begin{tabular}{|c|c|c|c|c|}
\hline Analysis criteria & Federal Republic of Germany & France & $\begin{array}{c}\text { United States of } \\
\text { America }\end{array}$ & Russian Federation \\
\hline $\begin{array}{l}\text { Organizational } \\
\text { structure }\end{array}$ & $\begin{array}{l}\text { Under authority of (Germany } \\
\text { Finance administration) }\end{array}$ & $\begin{array}{l}\text { Under authority of } \\
\text { (Major administra- } \\
\text { tion of France state } \\
\text { finance) }\end{array}$ & $\begin{array}{l}\text { Under authority } \\
\text { of (Finance } \\
\text { Ministry of USA) }\end{array}$ & $\begin{array}{c}\text { Under authority of } \\
\text { (Finance Ministry of RF) }\end{array}$ \\
\hline $\begin{array}{l}\text { Competent author- } \\
\text { ities on control } \\
\text { and supervision }\end{array}$ & Federal tax administration & $\begin{array}{l}\text { General tax direc- } \\
\text { torate }\end{array}$ & $\begin{array}{l}\text { Internal income } \\
\text { service }\end{array}$ & Federal tax service \\
\hline $\begin{array}{l}\text { Unexpected char- } \\
\text { acter of audit }\end{array}$ & $《+»$ & $《-»$ & $\ll-»$ & $\ll-\gg$ \\
\hline Types of tax audits & $\begin{array}{l}\text { - Documental } \\
\text { - occasional selection } \\
\text { - special selection }\end{array}$ & $\begin{array}{l}\text { - CTA } \\
\text { - FTA } \\
\text { - diagnostic surveys } \\
\text { of the small business }\end{array}$ & $\begin{array}{l}\text { - extramural } \\
\text { - CTA } \\
\text { - FTA }\end{array}$ & $\begin{array}{l}- \text { CTA } \\
- \text { FTA }\end{array}$ \\
\hline $\begin{array}{l}\text { Right for receiv- } \\
\text { ing information }\end{array}$ & $《-»$ & $\begin{array}{l}\text { In all cases without } \\
\text { limitation }\end{array}$ & $\begin{array}{l}\text { In all cases with- } \\
\text { out limitation }\end{array}$ & $\begin{array}{l}\text { Practically without } \\
\text { limitation of the right for } \\
\text { receiving information }\end{array}$ \\
\hline Control term & $\begin{array}{l}\text { Limitation of the term is absent. } \\
\text { Terms vary depending on the } \\
\text { level of enterprise: } \\
\text { - at the big one }-25-30 \text { days; } \\
\text { - at the middle one in average } \\
\text { up to } 15 \text { days; } \\
\text { - at the small one } 6-8 \text { days }\end{array}$ & $\begin{array}{l}\text { Minimal 2-3 days, } \\
\text { Revision period - } \\
\text { one year (can be pro- } \\
\text { longed for } 2 \text { years } \\
\text { more) For n.p. - no } \\
\text { more than for } 1 \text { year }\end{array}$ & $\begin{array}{l}\ll-\gg \text { term limita- } \\
\text { tion }\end{array}$ & $\begin{array}{l}\text { CTA - } 3 \text { months (in } \\
\text { exceptional cases can be } \\
\text { prolonged for } 1 \text { month) } \\
\text { FTA - } 2 \text { months, can be } \\
\text { prolonged for } 4,6 \text { months }\end{array}$ \\
\hline Tax courts & $«+»$ & $«-»$ & $《-»\rangle$ & $《-»\rangle$ \\
\hline
\end{tabular}


During the research were revealed the following features of the tax control in the foreign countries:

- the unexpected character of tax audit can be considered as the essential difference between the countries; for example, in Germany the right for audit is realized unexpectedly while in France the audit is impossible without preliminary informing of the tax payer;

- in most countries is practiced the close cooperation with the audited tax payer;

- the types of audits in the analyzed countries are mainly equal;

- all tax administrators of the analyzed countries have the right for receiving the additional information;

- in Germany, USA, Netherland and Japan is no limitation of the control term while in Russia the control terms are distinctly fixed at the legislative level.

\section{Results}

On the base of the studied foreign experience the following improvements of the tax control system in Russia can be offered:

- creation of the most favorable social and administrative medium (USA, Canada, German, France, Italy, Japan);

- creation of the special structural subdivisions on the base of FTSI for the search for sided external information (France). In France the special attention is paid to the search for the sided external information. For this aim were created the special structures: at the departmental level - brigade for search and control of information, at the national one - the interregional brigades. The tax inspectors in France have the possibility to watch for organization during its activity, before the start of the tax audit.

Creation of additional institutions:

- tax court (Japan). In Japan the judicially appeal is realized in the National Tax court. The institute of the tax court also effectively functions in USA, Germany. Introduction of the tax court in the system of power authorities of Russian Federation allows increase the effectiveness of judicially solution of the tax controversies, because this institution guarantees the existence of the close specialists in the field of tax right of this authority and also the judges who make solutions on this type of controversies. The introduction of the institute of the tax court allows also remove the big part of load from the arbitration courts and courts of the general jurisdiction;

- tax policy (Italy). The Finance Guard or the Tax policy of Italy that exist for almost two hundred years and control the whole system of taxation in the country is worthy of the special attention among the authorities that control the taxation of natural and juridical persons in Italy. Such structures successfully exist in many countries including Germany and France.

It must be taken into account that the control work of the tax authorities in Russia prevents and interrupts the crimes in financial sphere. But investigation and clearance of the tax crimes are beyond the competence of the tax service. FTS of Russia is an executive and not the low-enforcement authority, in which connection it have not the operative-investigative methods of the work that allow investigate and solve the tax crimes, that is why, I think, the creation of the tax policy (based on historical experience - an analog of the tax policy existed in past) with the new powers for counterwork to the crimes that threaten the financial system of the state will be the effective mean of prevention of crimes in financial sphere. Introduction of the tax police allows more effectively and operatively check and realize information about the suspicious financial affairs and operations using the methods and means of operative-investigative activity and at presence of the signs of crime immediately make the decision on the criminal proceedings.

It must be noted that these ways of rise of the effectiveness of the tax control must be used taking into account the national and mental features of the Russian citizens. 


\section{Discussion of the results of research on the tax control system improvement in Russia}

Summing up the results of research we can separate its positive sides: the theoretical grounds of the existing tax control system of Russia were revealed, within the retrospective analysis were marked the main stages of the formation and development of the tax control system in Russia from the tenth century up to the present time. The relation of each stage with existing system was demonstrated, the features and differences of the Russian system were separated. As to the comparative analysis of the experience of the foreign countries it must be noted that this analysis was carried out in the group of countries what choice was not an occasional one, in particular, the comparison was done with the Russian system, the analysis was carried out on the several criteria that are the basic ones. According to the results of research were offered the forms and methods of control that are possible to be adopted in Russia. The absence of the graphically presented conclusions and offers according to the results of analysis can be considered as the flaw of the research.

The research contains the sufficient scientific novelty, elaborates several topical problems that can be used by the legislative authorities at the tax control system modernization. This work can be also interesting for the competitors for the scientific degree at writing the candidate and magister theses; in addition this material can be used in the higher school lectures on such disciplines as "tax administration", "organization and methods of the tax audits".

\section{Conclusions}

As the result of researches:

1. The tax control system of Russia is based on the rather clear legislative base. The forms and methods of the control correspond to the world principles. The distinctive feature is the open process of planning of the field tax audits. That is legislation fixed 12 criteria of assessment of the tax risks that are available for the tax payers. In the other words the assessment of the risk of the field tax audit is available for both the tax authorities and tax payers. In whole the existing Russian tax control system is effective and coped with the main aim of budget replenishment till the 2014 inclusive (the budget deficit was near 0,5\% of GDP and still at the level of 2013, whereas in 2016 deficit was 2,8 \% of GDP of the country) at the proper level, but taking into account the new geopolitical conditions it becomes obvious that the search for the more effective ways of the improvement of existing system is needed.

2. Russian state has the imposing experience of the tax control system formation and development. Within the research was carried out the retrospective analysis of this experience that allowed separate the main stages of the Russian tax control system formation and development, were fixed the main marker points of each of these stages of development and was determined what prototype or pre-image it have been.

3. The comparative analysis of the foreign experience allowed reveal the ways, methods and forms of the tax control that are possible to be adopted in Russia and one of the main is the creation of the tax court.

4. The analysis of the existing tax control system, retrospective and comparative analysis of the experience of the foreign countries allowed fix the main ways of improvement, namely:

- institution of the tax court (Japan, USA, Germany);

- structures of the search for the new information (France);

- tax policy (Italy, Germany, France, native experience).

Summing up the results of research we can make a conclusion that the tax control - is the dynamic process, so for raise the effectiveness of the control work of the tax authorities the forms of control-supervisory activity must be improved and the new methods of tax control must be introduced with the help of the native historical and foreign experience. Just the improvement of the methods of the control work of the tax authorities as the component of the tax administration is seems to be the single progressive way of the increase of the budget incomes at the expense of the tax proceeds that does not infringe the legal rights and interests of the tax payers. 


\section{References}

[1] Berestova, S. V. (2004). Nalogovye proverki v Soedinennyh Shtatah Ameriki. Rosy siiskii nalogovyi kur'er: Elektronnyi zhurnal, 13-14. Available at: http://www.rnk.ru/article/71747-red-nalogovye-proverki-v-soedinennyh-shtatah-ameriki

[2] Mishustin, M. V. (2010). Povyshenie kachestva i effektivnosti nalogovogo administrirovaniia. Rossiiskii nalogovyi kur'er, 13-14.

[3] Novikov, A. M., Il'iuhov, A. A. (2014). Puti resheniia nereshennyh problem pri rassledovanii nalogovyh prestuplenii. Rossiiskii sledovatel', 14, 41-43.

[4] Tsepilova, E. S. (2013). Osobennosti nalogovoi sistemy i nalogovogo kontrolia vo Frantsii. Finansy, 2, 68-71.

[5] Vasianina, E. L. Problemy opredeleniia ekonomicheskogo osnovaniia naloga po zakonodatel'stvu Rossiiskoi Federatsii i v praktike rossiiskih sudov. Pravovoi tsentr «Pravyi bereg». Available at: http://xwww.center-bereg.ru/1031.html

[6] Popova, L. V., Drozhzhina, I. A., Maslov, B. G. (2008). Nalogovye sistemy zarubezhnyh stran: uchebno-metodicheskoe posobie. Moscow: Delo i Servis.

[7] Linovitskii, Iu. A. (2009). Praktika nalogovogo kontrolia v zarubezhnyh stranah. Nalogi i nalogooblozhenie, 11.

[8] Lappo-Danilevskii, A. (1980). Organizatsiia priamogo oblozheniia v Moskovskom gosudarstve so vremen Smuty do epohi preobrazovanii. Saint Peterburg, 576.

[9] Federal'naia nalogovaia sluzhba. Available at: http://www.nalog.ru/rn34/

[10] Bykov, S. S. (2014). K diskussii o poniatii protivodeistviia ukloneniiu ot uplaty nalogov i ego znachenii v priznanii nalogovogo prava samostoiatel'noi otrasl'iu. Izvestiia IGEA, 1. Available at: http://izvestia. isea.ru/pdf.asp?id=18841 